Journal : JMMR (Jurnal Medicoeticolegal dan Manajemen Rumah Sakit), 10 (1): 13-21, April 2021

Website : http://journal.umy.ac.id/index.php/mrs

DOI $\quad$ : https://doi.org/10.18196/jmmr.v10i1.10279

\title{
The Effect of Patient Safety Culture on the Quality of Nurses' Performance
}

\author{
Ririk Harlinisari ${ }^{1 *}$, Djazuly Chalidyanto ${ }^{2}$, Ririn Indah Permatasari ${ }^{3}$ \\ ${ }^{1 *}$ Correspondence Author: ririk.harlinisari-2019@fkm.unair.ac.id \\ 1,2,3 Department of Health Policy and Administration, Faculty of Public Health, Universitas Airlangga, Surabaya, Indonesia
}

\begin{tabular}{l}
\hline I N D E X I N G \\
\hline Keywords: \\
Patient Safety Culture; \\
Performance; \\
Nurses;
\end{tabular}

Kata Kunci:

Budaya Keselamatan

Pasien;

Peforma;

Perawat;

\begin{abstract}
A B S T R AC T
Patient safety culture should be applied by all nurses in healthcare facilities. Yet, most of the time, nurses are not aware of its importance, resulting in patients' poor perception of the nurses' performance. This study identified the effect of patient safety culture on nurses' performance at Bakti Mulia General Hospital. This was a correlation-descriptive study, which selected all nurses as many as 28 at Bakti Mulia General Hospital by using simple random sampling. Data were collected through questionnaires and analyzed using univariate and bivariate analysis with Pearson Correlation test. The majority of the respondents had poor patient safety culture (46\%), and some had high patient safety culture (54\%). The majority of the respondents showed had poor performance (68\%), and some others had high performance (32\%). There was a significant effect on patient safety culture on nurses' performance at Bakti Mulia General Hospital.
\end{abstract}

Budaya keselamatan pasien merupakan budaya yang yang wajib dilaksanakan para perawat di fasilitas layanan kesehatan. Akan tetapi budaya ini seringkali dikesampingkan alhasil kinerja perawat dipersepsikan buruk oleh para pasiennya. Tujuan penelitian ini untuk mengetahui pengaruhbudaya keselamatan pasien dengan kinerja pasien di RSU Bakti Mulia. Penelitian ini merupakan penelitian deskriptif korelasi. Sampel dalam penelitian ini adalah semua tenaga kesehatan yang bekerja di RSU Bakti Mulia sebanyak 28 orang, dengan teknik simple random samplingsebanyak 28 orang perawat. Data dikumpulkan melalui instrumen kuesioner.Analisis data menggunakan analisis univariat dan bivariate yaitu uji Pearson Correlation. Hasil penelitian menunjukkan bahwa mayoritas responden memiliki budaya keselamatan pasien yang rendah (46\%), dan responden yang memiliki budaya keselamatan pasien yang tinggi (54\%). Kemudian mayoritas responden memiliki kinerja yang tinggi (68\%), dan yang memiliki kinerja yang rendah (32\%). Penelitian menyatakan terdapat pengaruh yang signifikan antara budaya keselamatan pasien dengan kualitas kinerja perawat RSU Bakti Mulia

(C) 2021 JMMR. All rights reserved

$\overline{\text { Article history: Received 2020-11-16; Revised 2020-12-22; Accepted 2021-02-25 }}$

\section{INTRODUCTION}

Human resources are essential assets for organizational development since they can give feedback for the betterment (Khan et al., 2012). Poor working environments may harm employee's safety at the workplace and may cause incidents. Incidents due to absence or incompatible safety in the workplace also may cause valuable financial and human capital loss. Therefore, occupational safety and health for employees need special attention (Stone, R.J., 2004).

Some previous studies showed accidents, injuries, and diseases at work become problems at work (Ford \& Tetrick, 2011). If an organization could reduce the level of unintended occupational accidents, diseases, and stress, absence for a medical reason, ignorance of work, and absence for other reasons will decrease in nature. While, the efficiency 
and effectiveness of the organization, work satisfaction, flexibility, and nurses' participation at work will improve (Stone, R.J., 2004). On the other hand, amid global concern on health treatment safety and quality, monitoring on health care by the regulators became an issue (Laverty, et al., 2012)

Patient safety is the key element in the health care system and has become a priority for most organizations in the world for the past decades (Davoodi et al., 2013). Patient safety means preventing unintended incidents or accidents that may happen in a certain period in serving health care to patients (Alhamadi., 2010).

Hospital is a place which has essential and sensitive roles due to its function of serving thousands of people. Some studies reported a lack of safety at hospitals (Khodabakhsh-nejad., 2004). Dangers and incidents at hospitals involved fire as a result of electrical shock, burns due to acid spill on hands, skins, or respiratory allergies due to chemical substances at hospitals, oxygen tank explosion due to over-pumping, falls and fracture or employee deaths due to falling from high places, patient fall from the bed, burn at surgical rooms due to cautery equipment, unprotected lamps explosion, and other minor incidents that often occur (Khodabakhsh-nejad., 2004).

A study conducted by Golafrooz et al. confirmed the effectiveness of the safety management program which discussed the improvement of knowledge, attitude, and behavior of medical staff and safety improvement at hospitals (Golafruz et al., 2011). Employee's perception of occupational health and safety management at general hospitals in Malaysia. They showed that employees would improve safety continuously when they knew that more transparent management could support actions for safety improvement (Abdullah et al., 2009). Some studies revealed the internal motivation of employees was important in promoting safe behavior (Conchie, 2013). Butt et al., (2012) reported the correlation between safety at work and staff commitment. McCaughey et al., (2013) also announced the role of perception of safety environment on work satisfaction and stress among employees at work. Shahidi et al., (2011) claimed the quality of employee's work-life affected their performance. In this study, a safe working environment is effective for improving the employee's performance. Koshki et al, (2012) showed a safe working environment affected improvement in personnel efficiency. Furthermore, Mardani et al., (2013) showed there was a positive and significant correlation between patient safety culture and the medical staff's performance. In Indonesia, studies about the effect of patient safety culture on nurses' performance are rarely done. Thus, this present study was brought to research upon this topic.

\section{RESEARCH METHOD}

This study was a correlation-descriptive study aimed to identify the effect of two variables. In this study, the independent variable was patient safety culture, while the dependent variable was nurses' performance quality. This study used a cross-sectional approach since the data collection was done at one time at Bakti Mulia General Hospital since this hospital has never conducted any study on this topic. The sample in this study involved 28 nurses, obtained by using Slovin formula and random sampling. Data were then collected through questionnaires and the analysis of the data used Pearson correlation test (Chi-Square). The variable was considered influential if its significance value was $<0.05$. 


\section{Characteristics Respondent}

\section{RESULT AND DISCUSSION}

\section{Characteristics Respondents based on Gender}

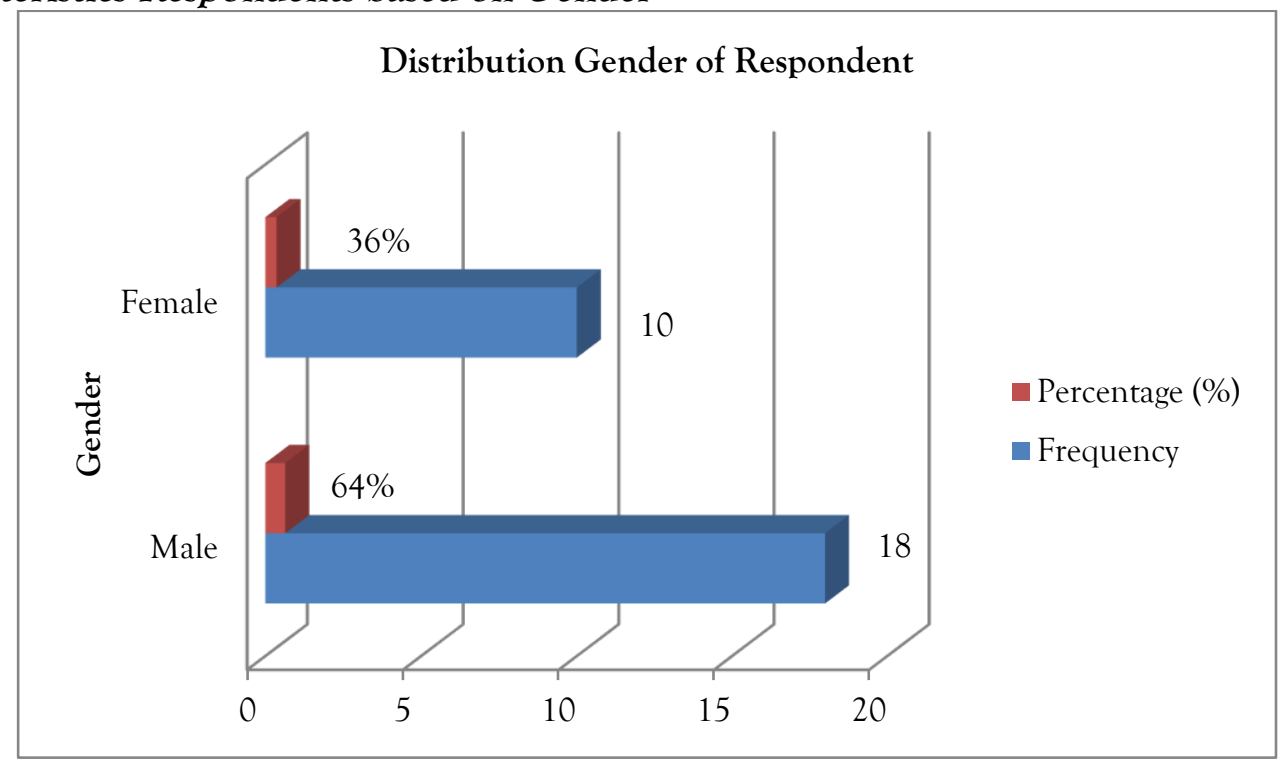

Picture 1. Distribution of Respondents based on Gender

According to Picture 1. most of the respondents were male 18 respondent (64\%), and the rest were female 10 respondent (36\%).

\section{Characteristics Respondents based on Education Level}

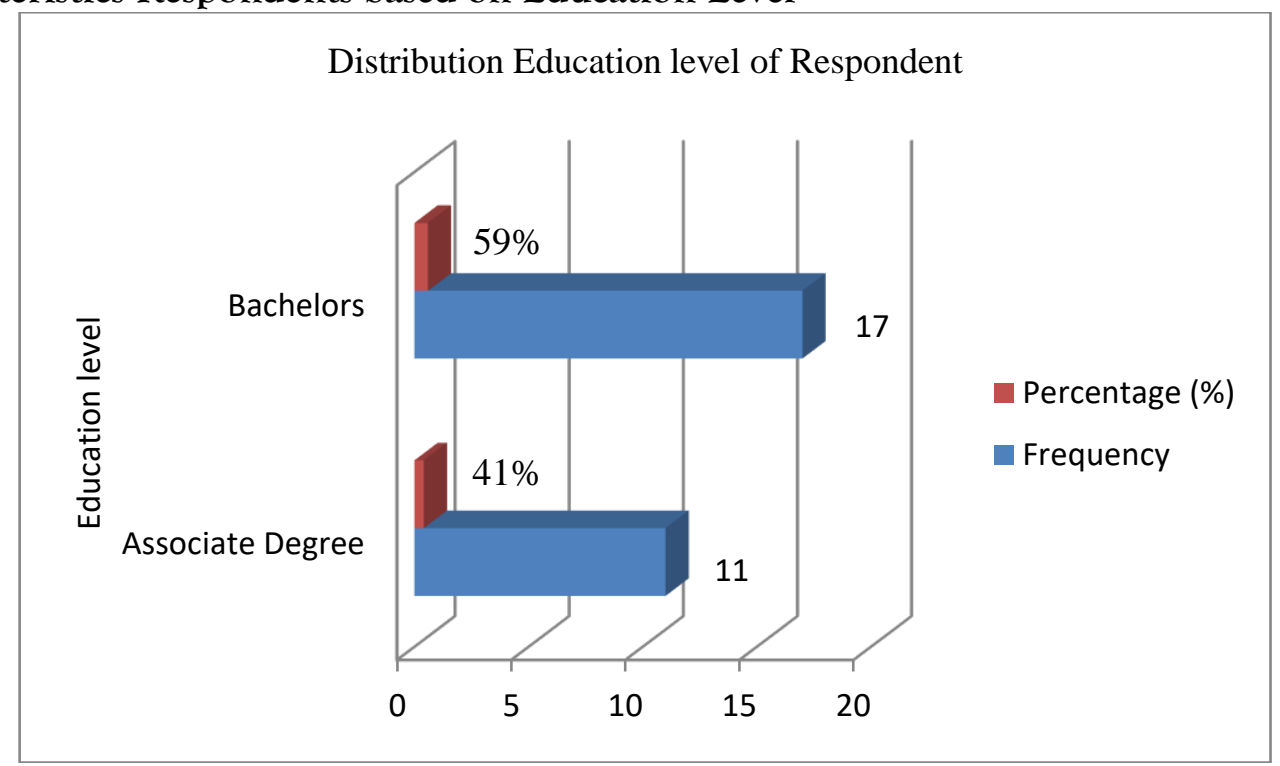

Picture 2. Distribution of Respondents based on Education Level

In Picture 2. most of the respondents had bachelor's degree 17 respondent (59\%), while others graduated from associate degree 11 respondent $(41 \%)$. 


\section{Distribution of Respondents based on Age}

Table 3. Distribution of Respondents based on Age

\begin{tabular}{lccc}
\hline & Age & Frequency & Percentage (\%) \\
\hline $20-25$ years & 9 & $30 \%$ \\
\hline $26-30$ years & 9 & $32 \%$ \\
\hline$>30$ years & 10 & $38 \%$ \\
\hline Total $(\mathrm{n})$ & 28 & $100 \%$ \\
\hline
\end{tabular}

Table 3. displays most of the respondents were at the age of 30 years $(38 \%)$, some of them were $26-30$ years old (32\%), and the rest were $20-25$ years old (30\%).

\section{Distribution of Respondents based on Work Period}

Table 4. Distribution of Respondents based on Work Period

\begin{tabular}{lcc}
\multicolumn{1}{c}{ Work Period } & Frequency & Percentage (\%) \\
\hline $1-5$ years & 6 & $22 \%$ \\
\hline $6-10$ years & 9 & $32 \%$ \\
\hline$>10$ years & 13 & $46 \%$ \\
\hline Total $(\mathrm{n})$ & 28 & $100 \%$ \\
\hline
\end{tabular}

Table 4. shows that the respondents mostly have worked for more than 10 years (46\%), and some of them have worked for $6-10$ years (32\%). While the rest have worked for $1-5$ years $(22 \%)$.

\section{Distribution of Respondents based on Patient Safety Culture}

Table 5. Distribution of Respondents based on Patient Safety Culture

\begin{tabular}{lcc}
\multicolumn{1}{c}{ Patient Safety Culture } & Frequency & Percentage (\%) \\
\hline Poor & 13 & $46 \%$ \\
\hline High & 15 & $54 \%$ \\
\hline Total (n) & 28 & $100 \%$ \\
\hline
\end{tabular}

Table 5. shows the respondents mostly had high patient safety culture (54\%), while some of them had poor patient safety culture (46\%).

\section{Distribution of Respondents based on Nurses' Performance}

Table 6. Distribution of Respondents based on Nurses' Performance

\begin{tabular}{|c|c|c|}
\hline Nurses' Performance & Frequency & Percentage (\%) \\
\hline Poor & 9 & $32 \%$ \\
\hline High & 19 & $68 \%$ \\
\hline Total (n) & 28 & $100 \%$ \\
\hline
\end{tabular}

In Table 6. it was noted that most of the respondents had high performance (68\%), and some of them had poor performance (32\%). 


\section{Cross Tabulation}

Table 7. Cross-tabulation between Patient Safety Culture and Nurses' Performance Quality

\begin{tabular}{|c|c|c|c|c|c|c|c|}
\hline \multirow{3}{*}{$\begin{array}{c}\text { Patient Safety } \\
\text { Culture }\end{array}$} & \multicolumn{4}{|c|}{ Quality of Nurses' Performance } & \multirow{3}{*}{$\mathrm{N}$} & \multirow{3}{*}{$(\%)$} & \multirow[t]{3}{*}{ Sig. } \\
\hline & \multicolumn{2}{|c|}{ Poor } & \multicolumn{2}{|c|}{ High } & & & \\
\hline & $\mathrm{N}$ & $\%$ & $\mathrm{~N}$ & $\%$ & & & \\
\hline Poor & 6 & 66.7 & 7 & 36.8 & 13 & 46.4 & 0.139 \\
\hline High & 3 & 33.3 & 12 & 63.2 & 15 & 53.6 & \\
\hline Total & 9 & 100 & 19 & 100 & 28 & 100 & \\
\hline
\end{tabular}

Table 7. showed $47 \%$ of the respondents had moderate patient safety culture. There was an effect of patient safety culture on nurses' performance quality with a P-value of 0.000 $(\mathrm{p}<0,05)$.

\section{Discussion}

\section{Characteristics Respondent}

Data analysis in Picture 1 above shows that most of the respondents were male, namely $64 \%$ (18 respondents) and the remaining 36\% (10 respondents) were female. The results of this study are in line with previous studies that have been carried out, which based on the frequency distribution of the characteristics of most respondents were male, $94.2 \%$ or as many as 129 respondents (Rivai et al., 2015). The distribution of respondents based on education level is shown in Picture 2, where most respondents have an undergraduate education background of 59\% (17 respondents). The high level of education of respondents in this case can affect the patient's safety culture, where this statement was revealed by the results of previous studies if the respondent with a Bachelor of Nursing education level had a high safety culture of $52.9 \%$. Furthermore, the results of this study indicate that the remaining 41\% (11 respondents) have an associate degree educational background.

Most respondents were known to be over 30 years old, namely with a percentage of $38 \%$ (10 respondents), the remaining 32\% (9 respondents) were between 26 years and 30 years old. The results of this study are in line with previous studies, in which the majority of respondents in the hospital were between $21-40$ years old, namely 156 respondents or $62 \%$ (Arini, 2018). In that age range, a person can be said to have had sufficient work experience and knowledge, especially in serving patients in hospitals. Data in table 2 above shows that most respondents in the hospital have worked for more than 10 years, namely $46 \%$ (13 respondents), and $32 \%$ (9 respondents) with a length of work between $6-10$ years. That is, the length of work that is more than 10 years shows that the more experience one has, so that it is expected to provide satisfactory service to patients.

The results of the analysis in table 3 show that the majority of patient safety culture in the hospital is included in the high category, namely 54\% (15 respondents). A high patient safety culture is in line with the results of previous studies which both concluded that out of 75 respondents, 37 respondents $(49.3 \%)$ were included in the low patient safety culture category and 38 respondents $(50.7 \%)$ were included in the high patient safety culture category. This statement is reinforced by previous research if from 48 respondents the proportion of implementing a good safety culture was 31 respondents $(64.6 \%)$, compared to those who were less good at 35.4\% (Irawan et al., 2017). A good patient safety culture will 
make the implementation of patient safety good. The implementation of a good patient safety culture is very important and will be even better if it is accompanied by awareness of the importance of patient safety, and knowledge by nurses.

Patient safety or hospital patient safety is a system that makes patient care safer, both from risk assessment, identification and management of things related to patient risk (Mulyana, 2013). A patient safety culture in the hospital that is quite good is shown in the form of unit cooperation, communication between medical personnel and well-established organizational learning. The existence of management support for patient safety culture efforts and patient transition transition are also known to be included in the aspect of patient safety (Arini, 2018). The high culture of patient safety in hospitals is caused by several factors, including the level of education and length of work of respondents in the hospital, where high education indirectly affects the knowledge and compliance of respondents in providing services and safety to hospital patients. The high level of patient safety culture is comparable to the results of the analysis of the nurse's performance level, which is also quite high, namely 68\% (19 respondents). This condition further illustrates that the higher the nurse's performance, the higher the level of patient safety culture. Conversely, if the lower the nurse's performance, it will affect the patient's safety culture.

\section{Patient Safety Culture}

Data from the analysis of table 3 also illustrates that 46\% (13 respondents) stated that the level of patient safety culture was poor. These data indicate that the possibility of errors or unexpected events in patients treated at Bakti Mulia Hospital is still high. The low level of patient safety culture at Bakti Mulia Hospital can be caused by several factors such as the support of the medical team and the working conditions of the nurses. Perception of management is a determinant factor for patient safety culture with a p value of $0.000<\alpha$ 0.05. Other factors that also affect patient safety culture are perceptions of management, work team support, job stress, and job satisfaction of nurses (Mulyati et al., 2016). In addition, the implementation of a mentoring program for nurses is known to have an effect on the level of application of patient safety culture (Nurmalia et al., 2014).

\section{Nurses' Performance}

The results of the distribution table 4 illustrate that the majority of nurses at Bakti Mulia Hospital are already high performance at 68\% (19 respondents). A high nurse performance is comparable to a high level of patient safety culture. In theory, the performance or quality of work of nurses in serving and providing care to patients in accordance with standard operating procedures and hospital rules in ensuring patient safety can affect the level of application of patient safety culture. The application of patient safety is influenced by five factors, namely individual factors and nurse performance, work environment factors, patient factors, organizational factors, and external factors. This explanation concludes that patient safety performance as a quality performance of a hospital (organization) is influenced by individual performance (in this case the nurse) in it (Wahyuningsih et al., 2013).

On the other hand, the low performance of nurses, which is $32 \%$, may be caused by several factors, namely, low level of knowledge and workload of nurses. The more 
responsibilities and workloads of nurses, the higher the concentration and knowledge required. More optimal performance, especially in the implementation of patient safety goals, can be improved by increasing the qualifications of human resources, especially nurses (Surahmat et al., 2018).

\section{Patient Safety Culture and Quality of Nurses' Performance}

Results showed patient safety culture affected nurses' performance quality. The effective implementation of occupational safety management programs in improving knowledge, behavior, and performance among medical staff (Golafruz et al., 2011). We also need to note that some studies also found employees continued improving safety at work when they knew more transparent management could support safety culture (Abdullah et al., 2009). In this context, the researchers have found a higher proportion of professional nurses became a predictor of reducing medical accidents and injuries in medical and surgical treatments (Hall et al., 2004).

The results of this study found improvement in patient safety culture could improve the quality of nurses' performance. Considering principles and standard procedures of patient safety will reduce the accidents and risks for patients and staff during enrolling and serving health care, accelerating services, and discharge. As a result, this will improve service demands and productivity at hospitals. This corresponded with a study conducted by Mardani, et al., (2013) who also found that patient safety culture gave positive and significant effects on nurses' performance quality.

The results of the study concluded that there was no relationship between work safety culture and the work quality of nurses ( $p$ value 0.20 ). Nurses with job satisfaction and high quality of work will have an impact on increasing patient safety culture in the hospital (Abdou \& Saber, 2011). According to several studies, employees will continue to improve safety, when they know that management is more openly supportive of safety activities (Abdullah et al., 2009). In this context, some researchers have shown that a higher proportion of professional nurses in the staff mix can be a predictor of reduced medical errors and wound infections in medical and surgical wards (Hall et al., 2004).

\section{CONCLUSION}

Based on the results of the research and discussion analysis that has been described above, it can be concluded that the majority of nurses at Bakti Mulia General Hospital are male $(64 \%)$, with the highest education level is Bachelor $(59 \%)$, the majority are over 30 years old $(38 \%)$ ), and a service period of more than 10 years $(46 \%)$. The results showed that the level of patient safety culture (54\%) and performance of nurses (68\%) in Bakti Mulia General Hospital, respectively, were included in the high category. Furthermore, based on the results of the bivariate analysis concluded that there was no relationship between patient safety culture and the performance of nurses at Bakti Mulia General Hospital with a significance value of 0.139 or greater than 0.05 . Based on the results and discussion of the research conducted, it is necessary to make improvements related to patient safety culture so that employee performance will increase. From the analysis, most of the respondents had high patient safety culture and performance. Improvement in patient safety should be done to advance nurses' performance. 
The results showed that patient safety culture had no effect on the performance of nurses at Bakti Mulia General Hospital. This means that the patient safety culture that has been implemented and carried out by the hospital has not been able to improve the performance of nurses, which in turn can have a positive impact on the development and quality of the hospital.

\section{ACKNOWLEDGMENT}

The authors thanked all parties who have helped contribute to this study.

\section{REFERENCE}

Abdou, H.A., \& Saber, K.M. 2011. A Baseline Assessment of Patient Safety Culture among Nurses at Student University Hospital. World Journal of Medical Sciences 6 (1): 17-26, 2011 ISSN 1817-3055 @ IDOSI PublicSations

Abdullah, N., Spickett, J., Rumchev, K., \& Dhaliwal, S. (2009). "Assessing Employees Perception on Health and Safety Management in Public Hospitals.," International Review of Business Research Papers, vol. 5, no. 4, pp. 54-72,

Alhamadi, H. (2010). "Assessment of patient safety culture in Saudi Arabian Hospital," Qual Saf Health Care, vol. 45, pp. 653-667 https://doi.org/10.1136/qshc.2009.033258 PMid:20430929

Arini, T. 2018. Budaya Keselamatan Pasien Berbasis Pemberdayaan Struktural Dengan Kepuasan Kerja Perawat. Tesis: Universitas Airlangga.

Bigdelly, M. (2010). "Studying the role of social climate on the quality of work life of worke RSU in the industry (Case study: East Azarbaijan Province), Applied Sociology.," Journal of Humanities Research of Isfahan University, vol. 21, no. 37.

Butt, H., Khan, F., Rasli, A., \& Iqbal, M. (2012). " Impact of work and physical environment on hospital nurses commitment," Int J Eco Res, vol. 3, pp. 33-43.

Conchie, S. (2013). "Transformational leadership, intrinsic motivation, and trust: A moderated-mediated model of workplace safety," J Occup Health Psychol, vol. 18, no. 2, pp. 198-210 https://doi.org/10.1037/a0031805 PMid:23506550

Davoodi, R., Shabestari, M.M., Takbiri, A., Soltanifar, A., Sabouri, G., Rahmani, S., \& Moghiman, T. (2013). Patient Safety Culture Based on Medical Staff Attitudes in Khorasan Razavi Hospitals, Northeastern Iran. Iranian J Publ Health, Vol. 42, No. 11, Nov 2013, pp.1292-1298.

Ford, M. T., Tetrick, L. E. (2011). Relations among occupational hazards, attitudes, and safety performance. Journal of Occupational Health Psychology, 16, 48-66. doi:10.1037/a0021296. PMid:21280944 
Golafruz, H., Ebadi, A., Salari, M., Shahri, M.G., \& Javadi, M. (2011). "The Effect of Safety Management Program on Knowledge, Attitude and Practice (KAP) in Health Care Pe RSU onnel," Journal of Sabzevar Unive RSU ity of Medical Sciences and Health Services, vol. 18, no. 2, pp. 98-103

Hall, L., Doran,D., \& Pink, G. (2004). "Nurse Staffing Models, Nu RSU ing Hou RSU , and Patient Safety Outcomes," J Nurs Adm, vol. 34, no. 1. https://doi.org/10.1097/00005110-200401000-00009.PMid:14737034

Irawan, A.G., Yulia, \& Muliyadi. 2017. Hubungan Supervisi Dengan Penerapan Budaya Keselamatan Pasien Di Ruang Rawat Inap Rumah Sakit Xx. Volume 5, Nomor 1, Juni.

Khan, A.H., Nawaz, M.M., Aleem, M., \& Hamed, W. (2012). "Impact of job satisfaction on employee performance: An empirical study of autonomous Medical Institutions of Pakistan". African Journal of Business Management Vol. 6 (7), pp. 2697-2705, 22 February, 2012 Available online at http://www.academicjournals.org/AJBM DOI: 10.5897/AJBM11.2222.

Khodabakhsh, V. (2004). Safety status of hospitals of Guilan University of Medical Sciences," MS Thesis Tehran University of Medical Sciences

Kooshki, M.S., Sari, A.A., Arab, M., \& Anglay, K.A. (2012). "Quality of life work and its relation to the productivity of nurses in hospitals of Shahid Beheshti University of Medical Sciences," Journal of School of Public Health Research Health, vol. 10, no. 4, pp. $81-90$

Laverty, A.A., Smith, P.C., Pape, U.J., Mears, A., Wachter, R.M., \& Millett, C. (2012). Highprofile investigations into hospital safety problems in England did not prompt patients to switch providers. Health Aff (Millwood)Mar;31(3):593-601. doi: 10.1377/hlthaff.2011.0810. PMid:22392671

Mardani, S., Tabibi, S.J., \& Riahi, L. (2013). "Relationship between Safety and Staff Performance in Hospital," International Journal of Hospital Research, vol. 2, no. 4, pp. 205-214

McCaughey, D., DelliFraine, J., McGhan, G., \& Bruning, N. (2013). "The negative effects of workplace injury and illness on workplace safety climate perceptions and health care worker outcomes," Saf Sci, vol. 51, no. 1 https://doi.org/10.1016/j.ssci.2012.06.004 